QIJIS: Qudus International Journal of Islamic Studies

Volume 6, Issue 1, February 2018

\title{
TAMING POVERTY IN NIGERIA:
}

\section{LANGUAGE, ZAKAT AND NATIONAL DEVELOPMENT}

\author{
Hamzah Abdurraheem, Saheed Badmus Suraju \\ Al-Hikmah University, Nigeria \\ bnsirooj1431@gmail.com \\ ibnsirooj1431@alhikmah.edu.ng
}

\begin{abstract}
Poverty, hunger and unemployment are social scourges ravaging many African countries, Nigeria inclusive. They constitute great obstacles to sustainable development and pose serious threats to security challenges. With her enormous human and material potentials, Nigeria ranks the $23^{\text {rd }}$ poorest country in the world. To tackle the menace of poverty, hunger and unemployment, successive Nigerian governments have initiated series of poverty eradication or poverty-alleviation programmes. But these programmes, due to corruption and inefficient leadership, availed Nigerians nothing, as $61.5 \%$ of Nigerians, according to the National Bureau of Statistics (NBS), are living below $\$ 1.25$ per day. Against this backdrop, this paper focuses attention on poverty and identifies Zakat, the third pillar of Islam, as a panacea for its alleviation. The paper discovers that lexical repetition, lexical collocation, synonyms, presuppositions and implicature are diverse linguistic features that are woven into the textual fabric of the Glorious Quran to foreground the paramount importance of Zakat as a social security towards poverty reduction. With a view to promoting national development and security, the paper concludes by advocating for an enabling law establishing a Central Zakat
\end{abstract}


(and Sadaqah) Administrative Board that will be saddled with the responsibilities of collecting Zakat and distributing it to the beneficiaries as stated in Suratu-t-Tawbah, verse 60 (9:60).

Keywords: Poverty, Development, Zakat, Zakatable Assets, Zakat Collection and Distribution Board

\section{A. Introduction}

Man, from time immemorial, has been facing the daunting challenges of survival as he struggles to meet his fundamental material needs. The innate tendency to fulfill his social needs and improve on his quality of life explicates his rationality to embark upon a unique line of development. Historical records right from the primitive age showed man's unabated desires for progress and development by improving from crude stone tools to the use of metal, from hunting and gathering of fruits to domestication of animals and growing of food crops, and from individualistic activity toward an activity which assumes communal participation (Rodney, 1972:3).

In our contemporary world, the concept of development is viewed from a tripodal perspective of social, economic and political processes geared towards qualitative changes and transformation of the people. In this respect, development is a process of gradual but steady economic expansion, peaceful and harmonious social relation and stable political structures that would grantee observable and constant improvement in the well-being of the people within the society. Thus, development has come to be associated with: material development, modernization, industrialization, scientific and technological advancement, urbanization, socio- cultural transformation, vertical and horizontal mobility, employment opportunity, mass literacy, emergence of specialized and independent occupational roles (Aremu, 2011:46) and conducive and serene atmosphere that guarantees security of live and property. Development and security intersect; they are connected. No nation can lay claims to 
development without security, and no nation can enjoy security without development.

In Nigeria, however, the trend of development is sliding. The country's National Development Plans: 1962-1968, 19701974, 1975-1980, 1981-1985, and all forms of Economic programmes that were instituted by various governments have not yielded the desired socio-economic benefits that would place Nigeria on the pedestal of development and transformation. Today, Nigerians languish in the throes of corruption, bad, insensitive and visionless leadership, poor policy implementation, incessant waves of tribalism, nepotism and violence, which have continued to endanger the polity and threaten the corporate existence of Nigeria.

Violence, according to Galtung (1990), cited by Best (2006:10), can be direct or structural. Direct violence is expressed in physical, psychological and counter value violence against an opponent. On the other hand, structural violence is expressed in such conditions as exclusion, deprivation, inequality and poverty.

Poverty is a universal phenomenon that poses serious threat to national development and security. A man or a country that is poor is not developed and is therefore insecure. Thus, every living society strives to curtail the menace of poverty as it creates a malignant tumour that wrecks have on humanity (Abdurraheem, 2012:1). This paper, therefore, focuses on poverty as a structural violence. It explicates, through a linguistic analysis of the Qur'an verses on zakat, how the institution of Zakat can be a prime alleviation of poverty in Nigeria so as to bring about National Security and Development.

\section{B. Discussion}

\section{Definition of Poverty}

Poverty refers to the state of lacking certain amount of material possession or money to maintain a comfortable standard 
of living. For the purpose of this paper, however, we shall subscribe to the definition offered by the World Bank Organization:

The most common used way to measure poverty is based on income. A person is considered poor if his or her income level falls below some minimum level necessary to meet basic needs. This minimum level is usually called the "poverty line". What is necessary to satisfy basic needs varies across time and society. Therefore, poverty lines vary in time and place, and each country uses lines, which are appropriate to its level of development, societal norms and values. (Wikipedia)

From this definition, we can deduce that poverty arises when someone's income cannot satisfy or meet his basic needs such as adequate and nutritious food, clothing, housing, clean water, education and health services. Thus, poverty, whether absolute or relative, remains a global challenge. The World Bank estimated that 1.29 billion people were living in absolute poverty in 2008. Of these, 400 million people in absolute poverty lived in Indian, and 173 million people in China. In USA one in five children lives in poverty. In term of percentage of regional populations, sub-saharan Africa of $47 \%$ had the highest incidence rate of absolute poverty in 2008 . Table 1 shows the 20 poorest countries in the world, most of which are African Countries, and presents their Gross Domestic Product (GDP) per capital measured in US \$ in 2011 (Isa, 2013).

\begin{tabular}{lcl}
\hline \multicolumn{1}{c}{ COUNTRY } & GDP PER CAPITAL AS OF \\
& 2011 \\
\hline 1.Democratic Republic of Congo & $\$$ & 348 \\
\hline 2.Liberia & $\$$ & 456 \\
\hline 3. Zimbabwe & $\$$ & 487 \\
\hline 4. Burundi & $\$$ & 615 \\
\hline 5.Eritrea & $\$$ & 735 \\
\hline 6.Central African Republic & $\$$ & 768 \\
\hline 7.Niger & $\$$ & 771 \\
\hline 8.Sierra Leone & $\$$ & 849 \\
\hline 9.Malawi & $\$$ & 860 \\
\hline
\end{tabular}




\begin{tabular}{lc}
\hline 10.Togo & $\$ 899$ \\
\hline 11.Madagascar & $\$ 9943$ \\
\hline 12.Afghanistan & $\$ 965$ \\
\hline 13.Guinea & $\$ 1,086$ \\
\hline 14.Mozambique & $\$ 1,085$ \\
\hline 15.Ethiopia & $\$ 1,092$ \\
\hline 16.Mali & $\$ 1,128$ \\
\hline 17.Guinea Bissau & $\$ 1,138$ \\
\hline 18.Comoros & $\$ 1,235$ \\
\hline 19.Haiti & $\$ 1,241$ \\
\hline 20.Uganda & $\$ 1,305$ \\
\hline
\end{tabular}

Table 1: The 20 poorest Countries in the world, (Source: nairaland)

Although, Nigeria is not among the twenty (20) poorest countries in the world, Popoola and Olaniyan (2011:1) claim that it (Nigeria) is rated among the 25 poorest country in the world, in spite of her rich human and material resources, as two thirds of the Nigerian population are struggling to survive under $\$ 1.25$ daily. In other words, they are victims of extreme poverty and excruciating hunger. According to the National Bureau of Statistics (NBS), 112.519 million Nigerians live in relative poverty, which means that $61 \%$ of the population is poor (Abdurraheem, 2012:1). This frightening ratio of poverty affects the standard of living as many Nigerians, deep-rooted in poverty, find it increasingly difficult to provide for themselves and their children, the primary basic needs of life, like food, clothing and shelter and clean water.

Business Day, $11^{\text {th }}$ May, 2012, reports that Nigeria ranks $3^{\text {rd }}$ globally in poor water sanitation access. This appalling revelation is regrettably lamented by Igali, the Permanent Secretary, Federal Ministry of Water Resources, thus:Nigeria has obtained third position as one of the world's poorest countries in gaining access to water and sanitation...the challenges are critical as women and children trek a long distance to fetch water from streams and ponds which are most time contaminated. 
In recognition of the menace and implications of poverty towards National Development, 191 United Nation member States, under the auspices of United Nation Development Program (UNDP), signed, in September, 2000, and agreed to try to achieve by the year 2015, the Millennium Development Goals (MDGs). These goals are:

a. eradicating extreme poverty and hunger;

b. achieving universal primary education;

c. promoting gender equality and empowering women;

d. reducing child mortality rates;

e. improving maternal health;

f. combating HIV/AIDS, malaria and other diseases;

g. essential environmental sustainability; and

h. developing a global partnership for development.

A critical assessment of the Millennium Development Goals reveals that poverty and hunger has a direct link with the other goals. In other words eradication or reduction of poverty will automatically have a spillover effect on the other goals.

\section{Successive Government Efforts of Eradicating or Alleviating Poverty}

Successive governments in Nigeria, perhaps since the inception of the First Republic, have initiated polices and embarked on programmes aimed at combating poverty, hunger, unemployment, social inequality, etc, with a view to improving the quality of life and transforming the standard of living of the Nigerian citizens. According to Adebayo (2005) and Atanda (2009) these policies and programmes are listed below:

a. National Accredited Food Production Programme (NAFPP);

b. Operation Feed the Nation (OFN);

c. Green Revolution Programme;

d. Go back to Land;

e. Directorate of Food, Roads, and Rural Infrastructure (DFRRI); 
f. Nigeria Directorate of Employment (NDE);

g. Better Life Programme (for Rural Woman);

h. Family Support Programme (FSP);

i. Family Economic Advancement Programme (FEAP);

j. Poverty Alleviation Programme (PAP);

k. National Poverty Eradication Programme (NAPEP);

l. National Economic Empowerment Development Strategy (NEEDS); and

m. Grassroots Empowerment Network

In spite of these poverty-eradication programmes, millions of Nigeria are still ravenously hungry and neck deep in poverty. In fact, over the years, poverty in Nigeria is alarmingly on the increase. These statistical figures from the National Bureau of Statistics confirm this assertion.

a. In 1980, 17.1 million people were in abject poverty

b. In 1985, 34.7 million people lived in abject poverty, i.e $43 \%$

c. In 1992, 39.2 million people were victims of abject poverty, $34.1 \%$

d. In 1996, 67.1 million people were in abject poverty, $64.6 \%$

e. In 2004, 68.7 million people were in the throes of abject poverty, $54.7 \%$

f. In 2010, 112.47 million people lived in abject poverty, $60.7 \%$

\section{Source: National Bureau of Statistics}

At present, the percentage of people living in abject poverty would have sky-rocketed, perhaps within the neighborhood of $64 \%$, giving the staggering numbers of people that were displaced by the 2012 flood disaster which ravaged 30 out of 36 states in Nigeria, claiming thousands of lives and destroying property and building worth billions of naira. If more than half of the Nigerian population is deeply -rooted in poverty and hunger, what has gone wrong with the poverty alleviation programmes? Are the programmes unattainable? Or does the problem lie with 
implementation? How can poverty be eradicated or reduced? What is the way out?

\section{Institution of Zakat}

Zakat, the third pillar of Islam, is a religious obligation. According to the consensus of Muslim scholars, zakat is an obligation for every wealthy Muslim who has enough money to satisfy Nisab at the beginning of a lunar year. Zakāt is instituted on the principle that wealth, given to mankind, is a trust from Allah and should be used to promote social justice (Siddique, 2008: 137). Allah owns the wealth because He is Ar-Razzāq, the Provider, and therefore entrusts the wealth to whom He wishes. From the wealth or resources owned by an individual, $2.5 \%$, is to be collected from him or her and further redistributed to take care of the poor, the needy and the dispossessed, who could not afford the basic needs of life. Thus, the goal of Zakat, if properly administered, is geared towards improving and transforming the standard of living of the underprivileged.

According to Hallaq (2007: 590-291), zakat was legislated at the start of Islam as a general obligatory charity, without limit, conditions and any fixed Nisab, Hawl (ayear) or rate. The situation continued until the Madnan phase began in the year 2. AH when Zakat based on Nusub (plural of Nisab) and Maqadeer began.

Linguistically, the word zakat is derived from the Arabic root za-kaa, which is a contraction of za-ka-wa (Cowan, 1974). Zakaa or zakawa suggests two basic meanings. First, it relates to purity, which is to purify oneself or someone from evil deeds, filth or sins. This notion of zakat as purifying oneself from filth or sins is contained in Sūratu-t-Tawbah (9:103): "Take (O! Muhammad) from their wealth (charity) in order to purify them...." Second, zakat means growth and increase, because when zakat is given, it leads to increase of property in this world and growth of religious rewards in the hereafter (Oloso, 2008:122). Zakat as growth and increase is implied in Sūratu-n-Nūr (24:56): "And establish prayer and give zakah and obey the messenger- that you may receive 
mercy". This notion of growth and increase is also echoed in Sūratu 'l-Baqarah (2: 261):

"The similitude or example of those who spend their wealth in the way of Allah is like a seed (of grain) which grows seven spikes; in each spike is a hundred grains. And Allah multiplies (His rewards) for whom he wills. Allah is all-Encompassing and all-knowing."

The prescription of zakat as a divine regulator of the socioeconomic affairs in human society is stylistically foregrounded in the Glorious Qur'an and in the Sunnah of Prophet Muhammad (S.A.W) through repetition. Zakat, as the nominal form of zakaa' or zakawa, is repeated in 32 places in the Qur'an (AbdulBaqi, 2001), where it means charity or alms-giving that is mandatory on the wealthy Muslims, with the exception of two places, where zakah means righteousness as in Süratu'l-kahf (18:81), and purification from sins (with regards to Prophet Yahya) as in suratuMaryam, (19:13). If the two exceptions are subtracted, AbdulBaqi's (2001) reckoning tallies with Hallaq (2007) who reckons that zakah is repeated thirty (30) times in the Qur'an, and in twenty-seven (27) places, it is linked or co-occurs with $A s$ Salāt (prayer). The three exceptions being sūratu-l-A'raf(7:156), Sūratu-r-Rūm(30:39) and Sūratu l-Fusilat (41:7). The stylistic implication of the co-occurrence of Salāt and Zakat is that while the former establishes and solidifies the link between man and 'Allah, his creator, the latter ties the bond of brotherhood, love and affection between the giver of zakah (the wealthy), and the beneficiaries (the poor and the needy) who constitute the regular members of the congregational salāt (prayer). For example, Allah says in Suratu'l-Baqarah (2:277): "Truly those who believe, and do deeds of righteousness, and perform As-Salat, and give zakat, they will have their rewards with their Lord. On them shall be no fear, nor shall they grieve."

In this verse, Īmān (monotheism), Deeds of righteousness, as-Salāt and Zakat collocate; and they combine together as the semantic field of religious obligation through which man draws rewards from Almighty Allah, and secures himself from the fear, 
grieve and torment of Hell fire in the hereafter. From this verse, the implicature to be drawn via inference is that where these four religious obligations are firmly established in human society, particularly the institution of zakat, such society shall be delivered from the perpetual fear of poverty, hunger and insecurity.

Furthermore, the institution of zakat as a developmental process that would facilitate and promote material advancement and economic empowerment is linguistically highlighted in the Glorious Qur'an. For instance, nafaqa (meaning be spent) its derivative form anfaqa (to spend) are predominately used in the Qur'an in connection with zakat. In other words, yunfiqu (he spends) which is the imperfect active of anfaqa, is often used synonymously with yuzakki, the imperfect active of zakkaa, in the Glorious Qur'an: Sūratu'l-Mumtahinah( 60:10); Süratu'l-Baqarah (2:272); Sūratu al-Imran (3:92); Sūratu'l-Hadìd (57:10), etc to mean, in most cases, obligatory charity, and at times to mean voluntary charity. In this respect, nafaqa, in addition to its various derivatives and mood patterns, is employed (in the Glorious Qur'an) thirty -three (33) times in relation to zakat as obligatory charity (AbdulBaqi, 2001:809).

Sadaqah or Sadaqāt are other lexical items that are used interchangeably with zakah both in the Qur'an and Sunnah. In Suratu-t-Tawbah (9:103) Allah says: "Take Sadaqah (alms) from their wealth in order to purify themand sanctify them with it, and invoke Allah for them...."

Again, in Surat-t-Tawbah (9:60), where the beneficiaries of zakat are mentioned, Allah uses sadaqāt as a loose synonymy to mean obligatory zakat. Both sadaqah and sadaqāt are repeated thirteen times (13) in the Qur'an with the meaning of obligatory zakah (AbdulBaqi, 2001:499; Hallaq, 2007:589). Commenting on the semantic relationship between sadaqah and zakahas synonyms, Hallaq (2007:590) writes:

By studying the Sunnah of the Prophet (S.A.W) one finds that it occurs in places with the meaning of an obligatory charity, and in other, with the meanings of both obligatory charity and voluntary 
charity, whereas in other places, it occurs with the meaning of voluntary charity only. In short, sadaqah and zakat carry the same meaning, though they differ in name, they agree in meaning.

What are the social implications of the linguistic or stylistic exposition of verses on zakat? They, among other things, imply that Allah puts a high premium on social security and an egalitarian society, which is a precursor for national development and security. The frequent repetition of zakaa or zakkaa, its derivative forms and mood patterns, nominal forms and synonyms are linguistic indicators that Allah encourages and favours communalistic existence, which can be guaranteed through zakat.

\section{Beneficiaries / Recepients of Zakat}

In Süratu-t-Tawbah (9:60), Allah itemizes the categories of people entitled to receive zakat. They include the following:

a. The poor: A poor person has nothing to cater for himself and his family

b. or cannot afford his basic needs for at least six months (alcUthaymin, 2007:68).

c. The needy: A needy person has possession but it is insufficient to satisfy his basic needs.

d. Those employ to work on zakat: These are the people who work in the collection and distribution of zakat.

e. Those whose hearts have been inclined (towards Islam): These are the people who have shown interest or have embraced Islam but entertain fear of being socially ostracized or financially incapacitated by their family members on account of their new faith (i,e Islam).

f. Freeing the captives:Zakat is also used to secure the freedom of people who are still held as captives. This category also include the apprentice who has completed his/her training but lack the wherewithal to stand on his/her own (Oloso, 2008:128). He or she is entitled to receive zakat with a view to establishing his/her vocation. 
g. Debtor:Zakat is to be given to someone who is weighed down by the burden of debt to enable sustain his final obligations.

h. In the cause of Allah: Zakat proceeds can be spent to prosecute battles to promote the cause of Islam. According to (Oloso, 2008:128), this cause of Allah includes building of schools, hospitals, orphanage home, Islamic centres, etc.

i. The Wayfarer that is the traveler: A wayfarer who needs money to meet expenses ofhis journey is entitled to be given Zakat. Oloso (2008:128) enumerates the following conditions before such a wayfarer can be given Zakat:

1. The journey should not be criminally or immorally motivated;

2. The wayfarer becomes poor during his journey though he may be rich at home; and

3. Nobody can lend him money during that period.

From the Sunnah of the Prophet (S.A.W), it is reported on the authority of Abu Sa'eed Al-Khudri who said that the messenger of Allah said:

Sadaqah is not permissible for the rich, except in five cases: one who fights in Allah's cause, or who collects it(the sadaqah), or a debtor or a man who buys it with his money, or a man who has a poor neighbour who has been given sadaqah and gives as present to the rich man. (Narrated by Ahmad (5/60); Muslim (no. 1044), Abu Dawood (no 1640) and An-Nasai (5/59).

In another related tradition, QabeesahIbnMukhariq AlHilali reported that the Messenger of Allah said to him:

Qabeesah, begging is not permissible but for one of these three (classes) of person: One who has incurred debt, for him begging is permissible till he pays that off, after which he must stop it; a man whose property has been destroyed by a calamity which has smitten him, for him begging is permissible till he gets what will support life, or will provide him with reasonable substance; and a person who has been smitten by poverty the genuineness of which is confirmed by three intelligent members froma m o $\mathrm{ng}$ his people. For him begging is permissive, till he gets what will support him, or will provide for him substance. Qaseebah, besides 
these three, (every other reason for) begging is forbidden, and one who engages in it consumes that which is forbidden. (Narrated by Ahmad (5/60); Muslim (no. 1044), Abu Dawood (no1640) and An-Nasa') (5/89).

The Quran verse and the traditions of the Prophet (S.A.W) on beneficiaries of Zakat reveals an implicature that there is a divine mechanism enshrined in Islam towards ameliorating the pangs of hunger and poverty and cushioning the effect of calamity and natural disasters. Islam views with utmost concern and sincerity of purpose the need to alleviate poverty and social exclusion. For example, the implicature to be drawn from Qur'an 9:60 is that, the institution of zakat, if successfully established, will operate in tandem with the objectives of the National Economic Empowerment and Development Strategy (NEEDS) which are employment generation and wealth creation, particularly for the beneficiaries on numbers 3,.4, 5 and 7 .

That zakat is an organized and a collective exercise and a state-controlled activity is implicated in beneficiary number 3 - those who work on zakat. The activities of collating data of eligible beneficiaries of zakat, collecting of zakat dues or nusub from the wealthy and distributing of zakat to eligible beneficiaries presuppose that the institution of zakat is a system that must be properly coordinated, efficiently managed and thoroughly supervised before it could perform its divine socio-economic regulator of human affairs.

\section{Zakatable Assets}

Zakatable assets are the material possessions or property on which zakat is payable. However, the amount of zakat to be paid by an individual depends on the amount of wealth and the type of assets the individual possesses. Each assets has its own nisab. Nisab is the minimum level that a Muslim's material possession must reach before he becomes eligible to pay zakat. The amount of zakat to be paid on capital assets (eg money) is $2.5 \%$ and is only payable on assets continuously owned over one lunar year 
that are in excess of the nisab. Hallaq (2007:601-621) and Oloso (2008: 123-127) discuss extensively zakatable assets and their Nusub, plural form of nisab. In addition to money other zakatable assets are gold, silver and copper, livestock, agriculture produce, stocks, merchandise for business, precious metals, mineral and sea products, shares and bonds, rented buildings and shops (they will treated as trade goods), etc. Personal assets such as clothing, household, furniture, and means of production like equipment, factories, or tools are exempted from zakat. For consideration of space, we shall not be able to present the nisab of all the zakatable assets. Few however, shall be attempted, leaning heavily on Oloso's (2008) illustration. Table 2 shows some zakatable items, their nisaband rate of zakat.

\begin{tabular}{llll}
\hline Wealth & Nisab & Rate of zakat \\
\hline $\begin{array}{l}\text { Gold, silver and } \\
\text { ornaments made from } \\
\text { them }\end{array}$ & $\begin{array}{l}85 \text { grams } \\
\text { of gold, } 595 \\
\text { grams of silver }\end{array}$ & $2.5 \%$ of value \\
\hline $\begin{array}{l}\text { Cash in hand and at } \\
\text { bank }\end{array}$ & $\mathrm{N} 425,000$ & $2.5 \%$ of value \\
\hline 3. & Mineral + sea products & any quantity & $20 \%$ of values \\
\hline 4. Agriculture produce & $\begin{array}{l}5 \text { awsuq } \\
(653 \mathrm{k})\end{array}$ & $\begin{array}{l}5 \% \text { in case of } \\
\text { irrigated land, 10\% if } \\
\text { watered by rain }\end{array}$ \\
\hline 5. Cow and Buffaloes & 30 in number & $\begin{array}{l}\text { For every 30, one } \\
\text { year old and from } 40 \\
\text { one 2-year-old }\end{array}$ \\
\hline
\end{tabular}

The nisab in agriculture produce (plants) which is five awsuq and 5\% for irrigated land and $10 \%$ if watered by land is premised on the following sayings of the messenger of Allah. It is reported on the authority of Abu Sa'eed Al-Khudri that the messenger of Allah (S.A.W.) said:

There is no sadaqah (i.ezakat) on less than five camels and also there is no sadaqah (i.ezakat) on less than five Awāq (of silver). And there is no zakat on farm produce less than five Awsuq. This is an authentic Hadith, narrated by al-Bukhari (no 1447) and Muslim (no 979). 
In addition, it is reported on the authority of Jabir ibn 'Abdullah that he heard the Prophet saying: "On what is watered by river and rain, $10 \%$ is due and on what is irrigated by a Saniyah, $5 \%$ is due". This is authentic Hadith, narrated by Muslim (no 981), Ahmad (3/341) and An-Nisai (5/41-42).

In this Table 3, Hallaq (2007: 602-606) enumerates the nusub on livestock such as cattle and sheep as follows:

\begin{tabular}{|c|c|c|}
\hline Wealth & Nisab & Rate of zakat \\
\hline \multirow[t]{11}{*}{ Camel } & 5 in number to 9 & 1 sheep \\
\hline & 10 in number to 14 & 2 sheep \\
\hline & 15 in number to 19 & 3 sheep \\
\hline & 20 in number to 24 & 4 sheep \\
\hline & 25 in number to 35 & $\begin{array}{l}1 \text { one-year-old she-camel } \\
\text { (Bintmakhadh) }\end{array}$ \\
\hline & 36 in number to 45 & $\begin{array}{l}1 \text { two-year-old she-camel } \\
\text { (BintLabūn) }\end{array}$ \\
\hline & 46 in number to 60 & $\begin{array}{l}1 \text { three- year-old she-camel } \\
\text { (Hiqqah) }\end{array}$ \\
\hline & 61 in number to 75 & $\begin{array}{l}1 \text { four- year-old she-camel } \\
\left(\text { Jaza'ah) }^{\prime}\right.\end{array}$ \\
\hline & 76 in number to 90 & 2 two- year-old she-camel \\
\hline & 91 in number to 120 & 2 three- year-old she-camel \\
\hline & 121 in number to 129 & 3 two- year-old she-camel \\
\hline \multirow[t]{6}{*}{ Sheep } & 1 in number to 39 & Nothing \\
\hline & 40 in number to 120 & 1 sheep \\
\hline & 121 in number to 200 & 2 sheep \\
\hline & 201 in number to 399 & 3 sheep \\
\hline & 400 in number to 499 & 4 sheep \\
\hline & 500 in number to 599 & $\begin{array}{l}5 \text { sheep } 1 \text { for additional } \\
\text { hundred }\end{array}$ \\
\hline
\end{tabular}

Note that the rates of zakat for the livestock discuss above are the female species of the animals that are zakatable. 
Whoever receives any of these female animals as zakat, the tendency to multiply increases when the female animals-mate. Thus, the institution of zakat promotes self-sufficiency and selfdevelopment, by generating employment opportunities for the jobless.

Strongly, Islam prohibits hoarding, and considers as hoarded wealth or material possession, property which the zakat has not been paid. Put differently, money (whether cash in hand, savings and fixed deposit), gold, silver and other zakatable assets which are in excess of nisab and are not paid over a period of one year, are considered, from Islamic point of view as hoarding. This position is vividly expressed in Suratu-t-Tawbah (9:34): "And those who hoard up gold and silver- (Al-Kanz; the money, the zakat of which has not been paid) and spendthem not in the way of Allah, announce to them a painful torment".

In this respect, the principles of zakat negate the capitalist hegemony of the winner-takes-all syndrome, individualistic assertions, hoarding of wealth and monopoly of merchandise. Thus, Qur'an 9:34 implies that the institution of zakat, if properly funded and utilized, entrenches social security, social equality and social justice which are corollaries of progress, peace, advancement, development and security in any human society.

\section{The Punishment on Zakat Defaulters}

Becauseof the apparently significant contributions of zakat to the spiritual consciousness and well-being of the people, Allah makes zakat, the third of pillar of Islam, as an obligatory charity and even spells out severe punishment on zakat defaulters. Again, we shall quote Süratu-t-Tawbah (9:34-35):

"And those who hoard up gold and silver (Al-kanz: money, the zakat of which has not been paid) and spend them not in the way of Allah, announce to them a painful torment On the day when that (al-kanz: money, gold, silver the zakat of which has not been paid) will be heated in the fire of Hell and with it will be branded their foreheads, their flanks and their back, (and it will be said to them): "This is the treasure which you hoarded for yourselves. Now taste of what you used to hoard". 
Prophet Muhammad gave an apt description of the punishment that would befall zakat defaulters in the following tradition:

If any owner of gold or silver does not pay what is due on him, when the day of Resurrection would come, plates of fire would be brought out for him; these would then be heated in the Fire of Hell, and his sides, his forehead and his back would be cauterized with them. Whenever these cool down (the process is) repeated during a day the extent of which would be fifty thousand years, until judgment is pronounced among, slaves, and he sees whether his path is to take him to paradise or to Hell (Al-Bukhari; 3:163).

In another tradition, the Prophet elucidated further the painful and humiliating punishment that awaits the affluent that refuse to give zakat. Abu-Hurairah narrated that Allah's messenger (S.A.W) said:

Anyone whom Allah has given wealth but he does not pay its zakat, on the Day of Resurrection, his wealth will be presented to him in the shape of a bald-headed male snake with two poisonous glands in its mouth and it will encircle itself round his neck and bite him over his cheeks and say: "I am your wealth; I am your treasure" (Fathu'l-Bāri, Vol.4 pages No 11-13; SahihAl-Bukhari, vol.6, Hadith No 88).

To corroborate his saying and warning on zakat defaulters, the Prophet read this Divine verse in Sūratu'l-c'Imrān (3:180):

Let not those who covetously withhold of that which Allah has bestowed upon them of His bounty (wealth) think that it is good for them (and so they do not pay the obligatory zakat). Nay, it will be worse for them; the things which they covetously withheld shall be tied to their necks like a collar on the Day of Resurrection.

The two Qur'an verses and Hadith of Prophet Muhammad (S.A.W) share similarities in terms of the collocates of the perdition that will descend on zakat defaulters. "Painful torment", "Plates of fire", "Fire of hell that will be branded on the foreheads, flanks and backs", "bald-headed poisonous male snake that will circle the neck and bite the cheek of the defaulters" conjure up concrete, visual and frightening images which speak volume of Allah's intense anger and wrath on those who refuse to pay zakat dues of their wealth. The images explicitly explain that Allah disgusts and 
abhors accumulation of wealth in the hands of few people. Oloso (2008: 131) observes thus:

The basic point in the levy of zakat is that wealth should not be accumulated in the hands of few people. It should be taken from the rich to be given to the poor and make the contribution fair and equitable. Zakat provides us with the opportunity of sharing our excess wealth with the less fortunate ones. We should know that we are just trustees to this wealth. Allah is the owner of both the wealth and ourselves...

\section{Establishing a CentralisedZakat (and Sadaqah) Administration}

In contemporary Muslim countries, Zakat administration is one of the institutions that sustain the economic well-being of the citizenry. For instance, in some countries, according to Abdurraheem (2012:8) zakat is collected through a decentralised and voluntary system, where eligible Muslims are expected to pay the zakat as ordained by Almighty Allah. Under this voluntary system, zakatcommittees are established and are saddled with the responsibilities of collecting and distributing zakat funds to the categories of people (beneficiaries) mentioned in Süratu-tTawbah (9:60).

In a handful of Muslim countries, including Saudi Arabia and Pakistan, zakat is obligatory and is collected in a centralized manner by the State. However, in countries like Jordan, Bahrain, Kuwait, Lebanon and Bangladesh, zakat is regulated by the State, but contributions are voluntary (Wikipedia).

Given the secular orientation of Nigerian Government, Zakat Administrative Board may be established, as an experimental process, at the State level, particularly in Muslim dominated states in North West, North East, North Central and South West geopolitical zones. To avoid being riddled with partisan politics, we propose that members of the Zakat Committee or Board should be appointed by, in states where there are Sharicah Courts of Appeal, the Grand Kadi of the Sharicah Court of Appeal. Although section 277; sub-section (1) and (2) of the 1999 constitution of the Federal 
Republic of Nigeria, with amendments 2011,does not include the appointment of Zakat Administrative Committee or Board as part of the statutory functions of the Kadi of the State Sharicah Court of Appeal, an enabling law can be enacted to this effect.

Section 100, sub-section 1 to 5 andsub-section 279 of the 1999 constitution of the Federal Republic of Nigeria, with amendments 2011, empowers State House of Assembly to enact laws, through bills passed by the House and presented to the Governor for assent.Suchlaws, if enacted should empower the Grand Kadi to determine the numerical composition, tenure and the terms of reference of Zakat Administrative Board. The Board or Committee should comprise people of high integrity, certified professionals, pious and knowledgeable clerics who are well versed in Islamic Jurisprudence, Muslim Traditional rulers, representative of farmers' association, bankers, businessmen etc.

It should be clearly stated that the Zakat Administrative Board or Committee being canvassed for in this paper is a voluntary contribution but regulated by the state through SharicahCourt of Appeal. Under this voluntary system, therefore, mass campaign on the minbarandin the mass-media (electronic and print) should be embarked upon by the Board or Committee on the significance and relevance of zakat in the socio-economic affairs of the Muslim Ummah, the punishment Allah prescribes for those who refuse to pay zakat, zakatable assets and other sundry issues relating to zakat. To win public acceptance and trust, the Zakat Board or Committee should be mandated to publish its activities to general public periodically.

In addition, we propose that the proceeds from zakat (and sadaqah) be utilized for the following three phases of activities. In the first phase, zakat proceeds should be expended on the poor and the needy which may include the widow, the orphans, the aged (both men and women) and those affected by disaster-storm, fire, flood and so on. This phase also includes the sick persons in hospital who need to settle their hospital bills. 
The second phase should focus on empowerment scheme. In this category, the beneficiaries of zakat include those who have acquired vocational skills, or have learnt a trade or a skill to set up scale businesses. The disbursement of zakat proceeds to this category of people will make them to create wealth, generate employment opportunities and attain self-sufficiency and self-independence. Part of the activities of the second phase is that proceeds from zakatshould be used to organize seminars, workshops and training programs on self-empowerment skills or schemes. The third phase is a long-term plan or program when the proceeds from zakat are surplus. Such surplus proceeds can be used to establish orphanage homes and hospitals, etc

Although, it has been implied above that, the Kadi of the SharicahCourt of Appeal is the regulatory body of the Zakat Administrative Board or Committee. However, the State Ministry of Finance and other financial regulatory bodies should play advisory roles in running the administration of Zakat Board. Apart from zakat collection and distribution, sadaqah(voluntary charity) should be included in the jurisdiction and sphere of the interest of the Zakat Administrative Board.

\section{Conclusion}

The foregoing exposition has shown that acute hunger and excruciating poverty are great obstacles to human development and that a country where hunger and poverty are deeply entrenched will be exposed to serious security risks. Furthermore, the linguistic analysis embarked upon in this paper reveals that many a Qur'an verse and Hadith of Prophet Muhammad (S.A.W.) on zakat imply that the institution of zakat, if firmly established and effectively managed, will promote and enhance social equality, social security and social harmony, thereby reducing the rate of violence, sufferings, hunger and poverty. Therefore, as a panacea for poverty reduction and alleviation, we advocate, through an enabling enactment, a state-coordinated Administrative Board or Committee that will oversee all affairs relating to zakat. 
Finally, if the establishment of a central Zakat Administrative Board or Committee materializes, it will, we hope, promote a more equitable redistribution of wealth, foster a sense of solidarity among members of the Muslim Community, promote feelings of love and strong emotional attachment and social harmony between the rich and poor, pave way for gainful economic activities, stimulate investment in productive business and entrench national development and national security. 


\section{REFERENCES}

AbdulBaqi, M.F. 2001. Al-Mu'jamu'l- Mufahras li alfazi 'l-Qur'an 'I-karim. Cairo: Daru'l-Hadith.

Abdurraheem, H. 2012. "Zakat: Panacea for Poverty Alleviation". A paper presented at the Convention /Workshop organized by Patriotic Youth Initiative Education (PYIPE), Kwara State Chapter, held at Federal Government College, Ilorin, between $16^{\text {th }}-21^{\text {st }}$, December, 2012.

Adebayo, R.I. 2005. "Poverty Alleviation Strategies in Nigeria: A lesson from the Institution of Zakat". Being a paper presented at a National Workshop on Islamic Political Thought and Institution at Bayero University between $24^{\text {th }}$ $-26^{\text {th }}$, August, 2005.

Ademola, O.T. 2011. "Global Change and Sustainable Development in Africa: A Role for South-South Cooperation." African Journal of Sustainable Development. Volume 1 No. 1 Ibadan: University of Ibadan Centre for Sustainable Development.

Al-'Uthaymin, M.S. 2007.SharhuBulūgh l-Marām min adillati l-ahkām. Beirut: Daru 'l-kutubu 'l-cilmiyyah.

Aremu, D.A. 2010. "Tourism and Development in Nigeria: Opportunities and challenges". In LabodePopoola et al (ed) Ibadan. 50 years of Nationhood: Experiences in and prospects for Sustainable Development in Nigeria. Ibadan: University of Ibadan centre for Sustainable Development.

Atanda, Y.F. 2009. "Zakat as a Source of Eradicating Poverty in our Society: a case study of Ilorin Metropolis". Being an unpublished Long Essay submitted to the Department of Islamic Studies, Al-Hikmah University, Ilorin.

Best, S.G (Ed). 2006.Introduction to Peace and Conflict Studies in West Africa: A Reader. Ibadan: Spectrum Books Limited. 
BusinessDay Newspaper. 2012. "Nigeria Ranks $3^{\text {rd }}$ Globally in Poor Water Sanitation Access". http://www.businessdayonline. com/NG/index.php/news/latest/37510_nigeria_ ranks_3rd_globally_in_poor_water_sanitation_access. Retrieved on 3rd May, 2013.

Cowan, J.M. 1974. A Dictionary of Modern Written Arabic. Beirut and London: LibrairieDuliban MacDonald and Evan Ltd.

Hallaq, M.S.H . 2007.Fiqh According to Qur'an and Sunnah. Vol. 1. Riyadh: Darussalam.

Isa. 2013. "20 Poorest Countries in the World" http://www. nairaland.com/1241944/20_poorest_countries_world. Retrieved on 3rd May, 2013.

Oloso, K.K. 2008. "Zakat as a Prime Poverty Alleviator" In ZakariyauOseni (ed) Fluorescence of Arabic and Islamic Studies in Nigeria: Festerift in Honour of Professor Wahab O.A. Nairu. Ibadan: FEBN Publishers, Plc.

Popoola, L and Olaniyan, O. (ed). 2010.50 years of Nationhood: Experiences in and prospects for Sustainable Development in Nigeria -Introduction and Overview. Ibadan: University of Ibadan Center for Sustainable Development.

Rahmatullahi. 2010. Zakat Distribution System must be reformed. http://twocircles.net/2010aug31/zakat_distribution_ system_must _be_reformed_dr_rehmatullahi.html. Retrieved on 3rd May, 2013.

Siddique, A.M. 2008. "Zakat (alms)” In CiromaTahir, AbdulHamid Muhammad and Halliru Abdu (Ed) Fiqhul-Ibadat. Yola: Mark of Excellence Printers.

Wikipedia. "poverty". http://en.m.wikipedia.org/wiki/poverty. Retrieved on 3rd May, 2013. 
